\title{
Research on the Value of Independent Directors of Universities: Evidence from the Resignation of Independent Directors of Universities ${ }^{3}$
}

\author{
Fei Che ${ }^{1, *}$ Yan Jiang ${ }^{2}$
}

\author{
${ }^{1}$ School of Business, Nanjing Xiao Zhuang College , Nanjing, Jiangsu 211171, China \\ 2 School of Business, Xiangtan University, Xiangtan, Hunan 411005, China \\ *Corresponding author. Email: chefei79@126.com
}

\begin{abstract}
In this paper, using Notice No.11 of Education Department in 2015 as an exogenous event, we test the value of independent directors of universities when they resign from the listed companies. First, we find that the market reaction is negative and significant. Moreover, the reaction has the characteristics of state-dependence. It means that the market reaction of state-owned listed companies is significantly negative, while the non-state-owned listed companies is significantly positive. Second, the governance mechanism of independent directors of universities as special committee members is limited in state-owned listed companies. Third, in the short term, independent directors of universities with good reputation have played a significant role in non-state-owned listed companies, but the market is not optimistic about this resource support function in the long term. In a word, the main way for independent directors of universities to exert their value is to supervise and consult in the listed companies. Therefore, the governance mechanism of special committees should be further improved to improve the efficiency of independent director system.
\end{abstract}

Keywords: the value of independent directors of universities, resignation, market reaction

\section{INTRODUCTION}

Hiring independent directors with academic backgrounds is a fashionable practice for the board of directors of listed companies in recent years. In particular, influenced by the "no. 18 document" of the central organization department in 2013, a large number of official directors resigned in a hurry, making relatively low-profile university teachers crowded into the board of directors of listed companies. According to public information statistics in the past two years, about one out of every three independent directors of listed companies in Shanghai and Shenzhen Stock Exchange is a teacher from the university, which is far higher than that of the officials. This phenomenon has attracted attention from all of the society, and has aroused widespread questions: do independent directors of these universities exert their supervision and consulting functions by providing advice and preventing risks for listed companies by their professional ability, or do they use their reputation or academic influence to create tangible value for listed companies and improve public trust in companies? If it is the former, professional knowledge of the university independent directors will help improve the overall governance level of listed companies; If it is the latter, the intangible resources contained in the identity of independent directors of the universities will inevitably destroy the market environment of fair competition. Therefore, it is of great significance to identify and evaluate the role of independent directors of the universities, both for academic accumulation and policy making, which will be researched in our paper.

However, empirical investigating the real value of independent directors of universities is not easy, the reason is whether that companies hire independent directors of universities, whether to accept appointment, and whether resign during the executing, which will be affected by the characteristics of company, which resulting in the problem of endogeneity will probably affect the robustness of the research conclusion. Fortunately, the notification issued by the general office of the ministry of education in November 2015 on the special inspection of party and government leading cadres' part-time work in enterprises provided a natural experiment for the research of this paper. A large number of independent directors of universities have to resign from their posts, according to the notification, which requires that the leading cadres above the deputy department level of universities are not allowed to serve as independent directors of listed companies. According to incomplete statistics, more than 270 independent directors resigned within one month since the Notice was issued. This is another resignation of independent directors of universities after the resignation of official independent directors of listed companies in 2013. The release of "Notice" leads to the "passive resignation" of 
independent directors of universities, which is different from the "active resignation" of independent directors in previous studies. This will greatly reduce the influence of endogenous factors of the company on the resignation behavior of independent directors of universities, and provide experimental data for the test of this paper.

By using the event research method, investigating the market reaction five days before and five days after the resignation announcement of independent directors of universities, this paper finds that: first, the market reaction to the resignation of independent directors of universities is significantly negative, indicating that independent directors of universities have played a positive role in the practice of corporate governance. Second, the strength of the market response is not affected by the level of independent directors, but by the nature of the enterprise. Third, independent directors of universities play a positive role in corporate governance mainly through their reputation and academic influence. The conclusion of this paper strongly answers the public and media's speculation and doubts about the value of independent directors of universities.

\section{LITERATURE REVIEW AND RESEARCH HYPOTHESIS}

\subsection{The Nature of Ownership and the Value of Independent Directors of Universities}

According to the Efficient Market Hypothesis (Fama,1970) [1], the market can react to the resignation announcement of independent directors. Specifically, if independent directors play a positive role in corporate governance, the market will react to the announcement of resignation with a downward trend, and vice versa. Compared with ordinary independent directors, independent directors of universities are more independent and professional, and the market reaction to their resignation should be significant. On the one hand, independent directors of universities have strong independence, because of their high degrees, the rich professional knowledge and scientific research abilities, and macro knowledge, who are not subject to the restrictions of the industry, can give many effective suggestions on corporate governance, have the abilities to advise for the company, guard against risk to develop supervisory and advisory function. On the other hand, independent directors of universities have good reputation. According to the Reputation Hypothesis (Fama, 1983) [2], in order to maintain their own reputation and the value of human capital, independent directors of universities would be more willing to actively and diligently fulfill their supervision responsibilities and completing their work of independent directors more responsibly instead of conspiring with the managers. At the same time, for listed companies, independent directors of universities with good reputation is a special kind of intangible resources, which has the signal transmission effect to improve the corporate image and gain the trust of investors. Hiring independent directors of universities with good reputation is convenient to the investment and financing activities in the capital markets, also to gain more resources. Some existing studies have confirmed that independence and professionalism are the core of the independent director system to maintain its vitality and realize its value.

Therefore, from the perspective of Agency Theory, if the independent directors of the universities resign according to "Notice" from the department of education in 2015, the CAR in the window periods will be significantly negative. In general, independent directors of universities may exert their value in corporate governance through two ways: (1)to provide professional knowledge, strategic support and supervision functions for the companies, and improve the scientific decision-making of the companies;(2) to provide the company with "social resources", bring the effect of sign transmission, alleviate the asymmetry of external information, and open the convenient door of investment and financing for the company. Therefore, the influence of the forced resignation of independent directors of universities on the value of the company depends on the mechanism of the two different approaches.

Under the institutional background of China, these two different approaches may have different manifestations in companies with different nature of ownership. State-owned enterprises have congenital political connection and bank connection compared with private enterprises (Deng et al., 2016[3]; Jiang etc.,2017[4]), and have the congenital superiority in resource acquisition, and are sheltered by the capital market. However, the lack of efficiency of incentive mechanism and institutions makes the state-owned enterprises relatively weak profession. Therefore, the motive of hiring independent directors of universities to gain social resources in state-owned enterprises is not strong, but to use their professional knowledge and ability to guard against risks and make scientific decision for the companies, due to the needs of the development of enterprises. As for non-state-owned enterprises, social resources are of great significance to their survival and development, and they have a strong incentive to hire independent directors of universities with good reputation to improve the corporate image and obtain social resources of investment and financing. However, in the long run, this kind of intangible resources is not conducive to the establishment of fair competition among companies and harmonious capital market, and even dissimilates the supervision and consulting functions of independent directors of universities. Therefore, the following hypothesis is proposed in this paper:

$\mathrm{H} 1$ : The market reaction of forced resignation of independent directors of universities is related to the nature of ownership.

H1a: After the forced resignation of independent directors of universities, state-owned enterprises have suffered a negative impact, and their market reaction is significantly negative.

H1b: after the forced resignation of independent directors of universities, non-state-owned enterprises suffer a positive impact, and their market reaction is significantly positive. 


\subsection{Supervision, Consultation and Independent Directors' Value of State-owned Listed Companies}

As mentioned above, the influence of forced resignation of independent directors of universities on corporate value depends on the mechanism of supervision and consultation function and resource function, which embody the supervision and consultation function in the state-owned listed companies. For the supervision and consulting functions, independent directors of universities not only need to actively prevent the rent-seeking behavior of the managers and the large shareholders' encroachment, but also need to rely on professional knowledge and strong personal ability to provide suggestions and opinions to the management. However, since the whole process of independent directors' fulfillment of duties cannot be observed, most studies assume that independent directors undertake a certain function in the director board. Theoretically, the observable information includes whether the independent director is a member of a special committee, as well as the educational background, specialty, background and professional title level of the independent director, which can reflect their performance of supervision and advisory functions.

Some studies have proved that the establishment of audit committees with independent directors in listed companies can reduce the probability of financial restatement and the possibility of financial fraud (Abbott, 2004[5]; Yang and Yin, 2006 [6]). Niu and Liu (2008) [7] found that independent directors serving as members of the special committee is beneficial for the supervision function and can bring significant governance premium to investors. $\mathrm{Cu}$ (2015) [8] found that independent directors serving as members of the compensation committee are conducive to fulfill their supervision function. In addition, some scholars have found that academic background of universities can significantly improve corporate performance(Ma, 2016[9]), especially independent directors with financial background play a stronger role in promoting corporate performance (Adams, 2016 [10]), which is conducive to improving the quality of accounting information (Xiang, 2014 [11]), reducing the risk of stock price collapse (Liu et al., 2015 [12]; Zhao, 2017 [13]). However, the scholar thinks that independent directors of universities only focus on the theoretical basis and ignore the realities, limited experience in commercial operation limits their decision-making level, academic expertise could not help enterprise operation, and scholars are engaged in scientific research in academic institutions, teaching and administrative work, which occupies a lot of time. As a result, they cannot effectively perform their duties (Agrawal and Chen, 2011 [14]). Based on the above analysis, this paper proposes following hypothesis:

$\mathrm{H} 2$ : The market reacts more negatively to the resignation of the independent directors of universities in the state-owned listed companies who serve as members of the special committee.

\subsection{Resource Support and Independent Director Value of Non-state-owned Listed Companies}

Apart from playing the supervision and consulting function with solid theoretical foundation and acute critical thinking ability, independent directors of universities may also play the "resource support" function through the unique intangible resources of independent directors of universities, which is mainly reflected in non-state-owned listed companies. First of all, Chinese society has always been regarded as an emphasis on interpersonal relationship and social network society. Chinese society of "relationship" is not only a kind of resources, but also is a kind of resources, which can bring the listed company especially non-stateowned listed companies' various benefits (Lei etc., 2017 [15]). So independent directors of universities with the "relationship" resources are favored by listed companies. Due to the special identity of independent directors of universities, it is convenient for them to know research experts, industry experts and scholars of universities, who have extensive social network (Chen et al.,2012 [16]).Such social network is the link between enterprises, universities and governments, and can provide enterprises with various social capital or resources (Booth and Deli,1996 [17]).For example, Farina (2009) [18] used the network data of interlocking directors of Italian Banks and non-financial listed companies to study and found that Banks are often in social networks, which can bring key resources to the company, and the higher the network center, the better the financial performance. Liu et al. (2015) [19] also found that the social network of independent directors is conducive to improving the efficiency of enterprises' mergers and acquisitions in other part of China. Moreover, even if independent directors of universities do not use social network, they can also play a symbolic function, representing the potential social resources they can use (Lin,2002 [20]).Further analysis shows that the good reputation of independent directors of universities has the function of information transmission, which is conducive to alleviating the degree of information asymmetry of listed companies. Investors usually employ independent directors of universities with good reputation, especially independent directors of famous universities, as indicators to evaluate the value of listed companies. Then, the value of listed companies with independent directors of universities will be greater (Vafeas, 1999 [21]), and are more likely to be labeled as good companies and standard companies. The greater the value, the easier it is to get the favor of investors, which in terms of financing has a greater advantage. In addition, considering the protection of reputation and the aura of high academic degree, the more part-time positions independent directors of universities have, the more diligent and responsible they are in fulfilling their supervision obligations, and the less likely they are to be absent from board meetings (Xie et al., 2016 [22]), and the more conducive they are to improving the quality of information disclosure of listed companies (Wang et al., 2013 [23]). Based on the above analysis, this paper proposes the 
following hypothesis:

H3: The market reaction to the resignation of independent directors of universities with better reputation in non-stateowned listed companies is more negative.

\section{EMPIRICAL RESEARCH DESIGN}

\subsection{Sample Selection}

This paper provides a natural experiment to test the value of independent directors of universities. To analysis independent directors of universities to resign after the ban, through searching company announcement in Wind database, this paper collected the data about the independent directors resignation of listed companies and the reason and the personal working experience of each independent directors to resign on which the ministry of education "Notice" issued from November 11, 2015 to June 30, 2016 by hand.

On this basis, listed companies in the financial industry, listed companies under special treatment, listed companies with missing trading data, listed companies whose independent directors have expired, and listed companies with major events such as major reorganization are excluded. Finally, 252 independent directors resigned from the 240 listed companies belong to leading cadres of party and government mentioned in the "Notice".

\subsection{Research Model and Variable Definition}

This paper adopts the event research method to investigate the market value of independent directors of universities, and refer to existing literatures such as Nguyen and Nielsen (2010) [24] to construct the following testing model to investigate the mechanism of independent directors of universities.

\section{Model1:}

$\mathrm{CAR}=\mathrm{a}_{0}+\mathrm{a}_{1}$ comittee $+\mathrm{a}_{2}$ state $+\mathrm{a}_{3}$ ratio $+\mathrm{a}_{4}$ boar_size $+\mathrm{a}_{5}$ top 1 $+a_{6}$ tenure $+a_{7}$ ceo $+a_{8}$ size $+a_{9}$ roe $+a_{10}$ lev $+a_{11}$ dnum $+a_{12}$ level $+\varepsilon$ Model2:

$\mathrm{CAR}=\mathrm{a}_{0}+\mathrm{a}_{1}$ fame $+\mathrm{a}_{2}$ state $+\mathrm{a}_{3}$ ratio $+\mathrm{a}_{4}$ boar_size $+\mathrm{a}_{5}$ top 1

$+\mathrm{a}_{6}$ tenure $+\mathrm{a}_{7}$ ceo $+\mathrm{a}_{8}$ size $+\mathrm{a}_{9}$ roe $+\mathrm{a}_{10}$ lev $+\mathrm{a}_{11}$ dnum $+\mathrm{a}_{12}$ level $+\varepsilon$ Variables in the model are defined as follows:

\subsubsection{Market Response (CAR)}

According to Brown and Warner's method (1985) [25], the specific formula for abnormal rate of return on the first announcement date of resignation is: $A R=r_{i, t}-r_{m, t}$.

$\mathrm{r}_{\mathrm{i}, \mathrm{t}}$ is the daily rate of return of a stock considering the reinvestment of cash dividends, while $\mathrm{r}_{\mathrm{m}, \mathrm{t}}$ is the daily rate of return considering the reinvestment of cash dividends in the equal-weighted Shanghai Stock Exchange composite index and Shenzhen Stock Exchange index.

The announcement day of the resignation of the independent director of the university is the event date. This paper also calculates the cumulative abnormal rate of return (car) in different window periods of the event date. CAR $(-3,3)$, CAR $(-2,2)$, and CAR $(-1,1)$ are selected as the dependent variables.

\subsubsection{Special Committees}

According to the setting of special committees of listed companies, this paper constructs four dummy variables, namely, audit committee, compensation committee, strategy committee and nomination committee.

The audit committee $(\mathrm{C}$ audit $)$ indicates that the value of the independent director of the university serving as the audit committee member is 1 , otherwise 0 ;

The compensation committee(C_comp), indicates that the value of the independent director of the university serving as a member of the compensation committee is 1 , otherwise 0 ;

The strategy committee(C_stgy) means that the value of the independent director of the university serving as a member of the strategy committee is 1 , otherwise 0 ;

The nominating committee $\left(C_{-}\right.$nomn $)$, indicates that the value of the independent director of the university serving as a member of the nominating committee is 1 , otherwise 0 ;

\subsubsection{Reputation of Independent Directors of Universities}

Drawing on the reputation measurement method of independent directors of universities such as Huang et al. (2016) [26], we use whether independent directors are from "985" or "211" universities or national key major universities to measure their reputation. If independent directors are from these universities, it means that they are independent directors with good reputation.

\subsubsection{Other Variable}

Other variables are shown in table 1. 
Table 1 Other variables table

\begin{tabular}{|c|c|c|}
\hline Variable names & Symbol & Variable definition \\
\hline Ownership property & state & $\begin{array}{l}\text { According to the nature of ultimate controller, it is divided into private enterprises, } \\
\text { state-owned enterprises. The value of State is } 0 \text { and } 1 \text {, which represents private } \\
\text { enterprises, state-owned enterprises respectively }\end{array}$ \\
\hline $\begin{array}{l}\text { Proportion of independent dire } \\
\text { ctors }\end{array}$ & ratio & The proportion of independent directors in the board of directors \\
\hline Board_size & board & The number of directors of a company \\
\hline $\begin{array}{l}\text { Ratio of the largest } \\
\text { shareholder }\end{array}$ & top1 & $\begin{array}{l}\text { The proportion of the shares held by the largest shareholder in the company to the } \\
\text { total shares }\end{array}$ \\
\hline tenure & tenure & The tenure of independent directors \\
\hline $\begin{array}{l}\text { The combination of general } \\
\text { manager and chairman of the } \\
\text { board }\end{array}$ & ceo & $\begin{array}{l}\text { The value of the general manager and the chairman of the board held by the same } \\
\text { person is } 1 \text {, otherwise } 0\end{array}$ \\
\hline Firm size & size & The logarithm of total assets at the end of the previous year \\
\hline profitability & roe & The proportion of net profit to average net assets at the end of the previous year \\
\hline Debt ratio & lev & The proportion of net profit to average net assets at the end of the previous year \\
\hline $\begin{array}{c}\text { Independent directors with } \\
\text { concurrent job }\end{array}$ & dnum & The number of Independent directors with concurrent job in the listed companies \\
\hline $\begin{array}{l}\text { Administrative rankings of the } \\
\text { independent directors }\end{array}$ & level & $\begin{array}{l}\text { The county level and below is assigned with a value of } 1 \text {, the department level is } \\
\text { assigned with a value of } 2 \text {, and the provincial level is assigned with a value of } 3\end{array}$ \\
\hline
\end{tabular}

\subsection{Market Reaction to Forced Resignation of Independent Directors of Universities}

Table 2 shows the market reaction of forced resignation of independent directors of universities, in which Panel A and Panel B are the statistical results of AR (daily abnormal rate of return) and CAR (cumulative abnormal rate of return) respectively.

The results of Panel A show that: on the day of forced resignation of the independent directors of universities, the median value of AR is -0.0051 , which is significant at the significance level of $5 \%$. Although the mean value is not significant, it is also negative value -0.58 . However, the market may know the news of the resignation of independent directors of universities in advance, or the listed company does not announce the resignation of independent directors of universities until the end of the transaction, so the market may react in advance or lag behind. It can be found that the market reaction to the resignation of independent directors of universities is mainly concentrated on the third days before the announcement, first days after the announcement, second days after the announcement and third days after the announcement. The mean value and median value of AR on the third days before the announcement are -0.0039 and 0.0054 respectively, which are significant at the significance level of $10 \%$ and $1 \%$, which indicate that the market has learned the resignation of independent directors of universities in listed companies in advance. The mean value of AR on first days after the announcement is -0.0062 , which is significant at the significance level of $5 \%$. The median value of AR on second days and third days after the announcement is -0.2 and -1.23 , respectively, and significant at the significance level of $10 \%$ and $1 \%$, which indicate that some listed companies releasing resignation announcement of independent directors of universities at the right time, which makes the market reaction lag.

The statistical results of Panel B show that the mean value of car $(-1,1)$ is positive, reaching 0.0067 , which is significant at the significance level of $5 \%$.However, the median values of car $(-3,3)$ and car $(-4,4)$ are both negative, which are 0.0107 and -0.0168 , respectively, and both are significant at the significance level of $10 \%$.In general, although there are some positive values in the market reaction of forced resignation of independent directors of universities, they are mainly negative values, which may indicate that the market reaction to forced resignation of independent directors of universities in different types of companies is different.

As mentioned above, the role of independent directors of universities in the company is mainly realized through two ways: supervision and consulting functions and resource functions. However, under the background of China's system, the state-owned listed companies have the advantages of resources and insufficient incentive, so the value of independent directors of universities in state-owned listed companies mainly embodies in supervision and advisory functions. As for the resource-limited non-stateowned listed companies, hiring independent directors of universities is one of the important ways to make up for the insufficient resources. Thus, the motive and the economic consequences of the different nature of ownership of listed companies hiring independent directors of universities are different, thus forced resignation of independent directors in universities has different impacts on the stock prices of listed companies with different nature of ownership. Therefore, it is necessary to distinguish the nature of ownership to explore the market reaction of forced resignation of independent directors of universities. 
Table2 The market reaction of independent directors' forced resignation

\begin{tabular}{|c|c|c|c|c|c|c|}
\hline Window & $\mathbf{N}$ & Mean & T test & The positive to negative & Median & Wilcoxon test \\
\hline \multicolumn{7}{|c|}{ Panel A Daily abnormal rate of return (AR) } \\
\hline-5 & 252 & 0.0019 & 0.86 & 101:151 & -0.0035 & -1.30 \\
\hline-4 & 252 & 0.0014 & 0.63 & 119:133 & -0.0022 & -0.01 \\
\hline-3 & 252 & -0.0039 & $-1.82^{*}$ & $93: 159$ & -0.0054 & $-3.37^{* * *}$ \\
\hline-2 & 252 & -0.0009 & -0.49 & $104: 148$ & -0.0036 & $-1.77^{*}$ \\
\hline-1 & 252 & 0.0026 & 1.29 & $117: 135$ & -0.0016 & -0.31 \\
\hline 0 & 252 & -0.0014 & -0.58 & $107: 145$ & -0.0051 & $-2.18^{* * *}$ \\
\hline 1 & 252 & -0.0062 & $-2.44^{* * *}$ & $121: 131$ & -0.0018 & 1.36 \\
\hline 2 & 252 & -0.0004 & -0.20 & 101:151 & -0.0043 & $-1.89^{*}$ \\
\hline 3 & 252 & -0.0024 & -1.23 & $95: 157$ & -0.0071 & $-3.22^{* * * *}$ \\
\hline 4 & 252 & 0.0031 & 1.46 & $98: 154$ & -0.0052 & -1.35 \\
\hline 5 & 252 & -0.0007 & -0.29 & 110:142 & -0.017 & -1.34 \\
\hline \multicolumn{7}{|c|}{ Panel B Cumulative abnormal rate of return (CAR) } \\
\hline CAR $[-5,+5]$ & 252 & 0.0048 & 0.53 & $112: 140$ & -0.0126 & -1.11 \\
\hline CAR $[-4,+4]$ & 252 & 0.0032 & 0.46 & 110:142 & -0.0168 & $-1.7^{*}$ \\
\hline CAR $[-3,+3]$ & 252 & -0.0015 & -0.06 & 108:144 & -0.0107 & $-1.78^{*}$ \\
\hline CAR $[-2,+2]$ & 252 & 0.0056 & 1.00 & 109:143 & -0.0068 & 0.57 \\
\hline CAR $[-1,+1]$ & 252 & 0.0067 & $2.10 * *$ & $117: 135$ & 0.0042 & -0.03 \\
\hline
\end{tabular}

$*, * *, * * *$ mean significance level of $10 \%$, significance level of $5 \%$, and significance level of $1 \%$, respectively

\subsection{Market Reaction to Forced Resignation of Independent Directors of Universities in Listed Companies with Different Nature of Ownership}

Table 3 and table 4 analyze the market reaction of forced resignation of independent directors of universities in listed companies with different nature of ownership.

Table 3 shows the market reaction of the forced resignation of independent directors of universities in state-owned listed companies. From the mean value and median value of each window (especially the second and third window), the significance level of AR is significantly negative. The mean and median of CAR $(-5,5)$, CAR $(-4,4)$, CAR $(-3,3)$, CAR ($2,2)$ are all significantly negative. It can be seen that the market's response to the forced resignation of independent directors of universities in state-owned listed companies is significantly negative, which indicates that investors believe that independent directors of universities play a positive role in the corporate governance of state-owned listed companies, and the forced resignation of independent directors of universities will have a negative impact on the value of state-owned listed companies, which is consistent with hypothesis H1a. 
Table3 Market reaction of forced resignation of independent directors of universities in state-owned listed companies

\begin{tabular}{|c|c|c|c|c|c|c|}
\hline Window & $\mathbf{N}$ & Mean & T test & The positive to negative & Median & Wilcoxon test \\
\hline \multicolumn{7}{|c|}{ Panel A Daily abnormal rate of return (AR) } \\
\hline-5 & 137 & -0.0019 & -0.79 & $52: 85$ & -0.0034 & $-1.96^{* *}$ \\
\hline-4 & 137 & 0.0001 & 0.04 & $60: 77$ & -0.0032 & -0.76 \\
\hline-3 & 137 & -0.0004 & -0.18 & $51: 86$ & -0.0051 & $-2.05^{* *}$ \\
\hline-2 & 137 & -0.0015 & -0.68 & $54: 83$ & -0.0036 & $-1.79^{*}$ \\
\hline-1 & 137 & 0.0012 & 0.53 & $59: 78$ & -0.0029 & -1.11 \\
\hline 0 & 137 & -0.0066 & -2.56 & $52: 85$ & -0.0073 & $-3.22^{* * !}$ \\
\hline 1 & 137 & -0.0003 & -0.10 & $64: 73$ & -0.0024 & -0.05 \\
\hline 2 & 137 & -0.0040 & $-2.02^{* *}$ & $48: 89$ & -0.0055 & $-2.80^{* * * *}$ \\
\hline 3 & 137 & -0.0047 & $-2.07^{* *}$ & $47: 90$ & -0.0077 & $-3.37^{* * * *}$ \\
\hline 4 & 137 & -0.0004 & -0.18 & 53:84 & -0.0047 & -1.59 \\
\hline 5 & 137 & -0.0014 & -0.47 & $61: 76$ & -0.0028 & -0.99 \\
\hline \multicolumn{7}{|c|}{ Panel B Cumulative abnormal rate of return (CAR) } \\
\hline CAR $[-5,+5]$ & 137 & -0.0192 & $-2.20^{* *}$ & $54: 83$ & -0.0274 & $-2.64^{* * *}$ \\
\hline CAR $[-4,+4]$ & 137 & -0.0159 & $-2.08^{* *}$ & $50: 87$ & -0.0231 & $-2.95^{* * *}$ \\
\hline CAR $[-3,+3]$ & 137 & -0.0157 & $-2.17^{* *}$ & $51: 86$ & -0.0121 & $-2.96^{* * * *}$ \\
\hline CAR $[-2,+2]$ & 137 & -0.0105 & $-1.86^{*}$ & $54: 83$ & -0.0090 & $-1.97^{* *}$ \\
\hline CAR $[-1,+1]$ & 137 & -0.0056 & -1.11 & $55: 82$ & -0.0098 & -1.46 \\
\hline
\end{tabular}

$*, * *, * * *$ mean significance level of $10 \%$, significance level of $5 \%$, and significance level of $1 \%$, respectively

Table 4 is the market reaction of the forced resignation of independent directors of universities in non-state-owned listed companies. The statistical results of Panel A show that the mean value of AR in each window is positive from the beginning of window 0 , although the significance is not uniform, and the mean values of window 1 and window 4 are significant at the significance level of $5 \%$ and $10 \%$. The statistical results of Panel B on the cumulative abnormal return rate of the market(CAR) show that the mean test of car(-1,1), car(-2,2), car(-4,4) and car(-5,5) are all significantly positive, which shows that after the resignation of independent directors of universities in non-state-owned listed companies, the market is impacted positively. Namely, the investors think that for non-state-owned listed companies, the market environment of fair competition is the most important factor for a long-time development of the companies. Although in the short term hiring a reputable independent directors of universities is helpful to improve the companies' image, to obtain the social resources of investment and financing, to give full play to the function of resources support of independent directors of universities, in the long run, the intangible resources can distort the market resource allocation function, even dissimilate supervision and consultation function of independent directors of universities. Therefore, the forced resignation of independent directors of universities purifies the capital market, which is conducive to building a harmonious external governance environment. So, after independent directors of universities in the non-state-owned listed companies resign, the stock price suffers a positive shock, and the market reaction is significantly positive. The $\mathrm{H} 1 \mathrm{~b}$ hypothesis is verified. 
Table 4: Market reaction of forced resignation of independent directors of universities in non-state-owned listed companies

\begin{tabular}{|c|c|c|c|c|c|c|}
\hline Window & $\mathrm{N}$ & Mean & T test & The positive to negative & Median & Wilcoxon test \\
\hline \multicolumn{7}{|c|}{ Panel A Daily abnormal rate of return (AR) } \\
\hline-5 & 115 & 0.0064 & 1.63 & $49: 66$ & -0.0037 & 0.19 \\
\hline-4 & 115 & 0.0030 & 0.80 & $59: 56$ & 0.0010 & 0.78 \\
\hline-3 & 115 & -0.0081 & $-2.20 * *$ & $42: 73$ & -0.0071 & $-2.75 * * *$ \\
\hline-2 & 115 & -0.0003 & -0.09 & $50: 65$ & -0.0037 & -0.75 \\
\hline-1 & 115 & 0.0041 & 1.22 & $58: 57$ & 0.0004 & 0.69 \\
\hline 0 & 115 & 0.0046 & 1.05 & $55: 60$ & -0.0021 & 0.10 \\
\hline 1 & 115 & 0.0014 & $3.23 * *$ & $57: 58$ & 0.0004 & $2.11 * *$ \\
\hline 2 & 115 & 0.0031 & 0.91 & $53: 62$ & -0.0037 & 0.11 \\
\hline 3 & 115 & 0.0004 & 0.11 & $48: 67$ & -0.0071 & -1.21 \\
\hline 4 & 115 & 0.0073 & $1.78^{*}$ & $45: 70$ & 0.0011 & -0.19 \\
\hline 5 & 115 & 0.0002 & 0.06 & $49: 66$ & -0.037 & -0.86 \\
\hline \multicolumn{7}{|c|}{ Panel B Cumulative abnormal rate of return (CAR) } \\
\hline CAR $[-5,+5]$ & 115 & 0.0035 & $1.77 *$ & $58: 57$ & 0.0009 & 1.01 \\
\hline CAR $[-4,+4]$ & 115 & 0.0255 & $1.89 *$ & $60: 55$ & 0.0034 & 0.60 \\
\hline CAR $[-3,+3]$ & 115 & 0.0178 & 1.31 & $57: 58$ & -0.0007 & 0.44 \\
\hline CAR $[-2,+2]$ & 115 & 0.0255 & $2.34 * *$ & $54: 61$ & -0.0050 & 1.27 \\
\hline CAR $[-1,+1]$ & 115 & 0.0227 & $2.71 * * *$ & $62: 53$ & 0.0022 & 1.29 \\
\hline
\end{tabular}

$*, * *, * *$ mean significance level of $10 \%$, significance level of $5 \%$, and significance level of $1 \%$, respectively

\subsection{Regression Analysis on the Market Reaction of Supervision, Consultation and Forced Resignation of Independent Directors of Universities}

The univariate grouping test above shows that the market reaction of forced resignation of independent directors of universities is state-dependent, that is, independent directors of universities may have fundamentally different ways and mechanisms to play their roles in state-owned and non-stateowned listed companies. Due to the inherent resource advantages of state-owned listed companies, independent directors of universities have limited resource function, and more supervision and consultation function. Next, this paper uses multiple regression analysis to further investigate the specific mechanism of independent directors of universities exerting their value in state-owned listed companies.

This paper tests hypothesis $\mathrm{H} 2$ by independent directors of universities taking the position of special committees as a variable to measure their supervision and consultation function. Relevant empirical results are shown in table 5 . Table 5 examines the market reaction to their resignation of independent directors of universities serving as special committees. According to whole sample test result and the test result of the state-owned listed companies, a the market reaction is not significantly to independent directors of universities serving as a special committee, which suggests that the investors think in state-owned listed companies, independent directors of universities serving as a special committee did not play their role in company governance. This is not consistent with hypothesis H2.The main reason is that on the one hand, the establishment and operation mechanism of the special committee is defective. To a certain extent, it is only a dummy department set up by the listed companies to achieve the Governance Rules of the Listed Companies, which has not attracted the attention of the state-owned listed companies. On the other hand, due to the lack of corresponding supervision and incentive mechanism of independent directors, independent directors of universities fail to perform their supervision and consulting duties in special committees. Independent directors of listed companies, especially state-owned listed companies, may exert their value through other ways. 
Table 5 Test results of hypothesis 2

\begin{tabular}{|c|c|c|c|c|c|c|}
\hline \multirow{2}{*}{ Variable } & \multicolumn{3}{|c|}{ Whole samples } & \multicolumn{3}{|c|}{ Samples of state-owned listed companies } \\
\hline & CAR(-3,3) & CAR $(-2,2)$ & CAR $(-1,1)$ & CAR $(-3,3)$ & CAR $(-2,2)$ & CAR $(-1,1)$ \\
\hline C_audt & $\begin{array}{c}-0.0047 \\
(-0.27)\end{array}$ & $\begin{array}{c}-0.0088 \\
(-0.62)\end{array}$ & $\begin{array}{c}-0.0072 \\
(-0.64)\end{array}$ & $\begin{array}{c}0.0117 \\
(0.64)\end{array}$ & $\begin{array}{c}0.0070 \\
(0.48)\end{array}$ & $\begin{array}{c}0.0064 \\
(0.50)\end{array}$ \\
\hline C_comp & $\begin{array}{c}-0.0050 \\
(-0.27) \\
\end{array}$ & $\begin{array}{l}-0.0065 \\
(-0.43) \\
\end{array}$ & $\begin{array}{l}-0.0148 \\
(-1.22) \\
\end{array}$ & $\begin{array}{c}0.0056 \\
(0.28) \\
\end{array}$ & $\begin{array}{c}-0.0004 \\
(-0.03) \\
\end{array}$ & $\begin{array}{c}-0.0051 \\
(-0.37) \\
\end{array}$ \\
\hline C_stgy & $\begin{array}{l}0.0059 \\
(0.32) \\
\end{array}$ & $\begin{array}{l}0.0129 \\
(0.86) \\
\end{array}$ & $\begin{array}{l}0.0092 \\
(0.76) \\
\end{array}$ & $\begin{array}{c}-0.0073 \\
(-0.37) \\
\end{array}$ & $\begin{array}{l}0.0046 \\
(0.29) \\
\end{array}$ & $\begin{array}{l}0.0031 \\
(0.22) \\
\end{array}$ \\
\hline C_nomn & $\begin{array}{c}-0.0278 \\
(-1.51) \\
\end{array}$ & $\begin{array}{l}-0.0173 \\
(-1.17) \\
\end{array}$ & $\begin{array}{l}-0.0231 \\
(-0.35) \\
\end{array}$ & $\begin{array}{c}-0.0159 \\
(-0.78) \\
\end{array}$ & $\begin{array}{c}-0.0154 \\
(-0.95) \\
\end{array}$ & $\begin{array}{c}-0.0131 \\
(-0.92)\end{array}$ \\
\hline state & $\begin{array}{l}-0.0169 \\
(-1.07) \\
\end{array}$ & $\begin{array}{c}-0.0234 \\
\left(-1.84^{* *}\right)\end{array}$ & $\begin{array}{c}-0.0231 \\
\left(-2.26^{* *}\right)\end{array}$ & & & \\
\hline ratio & $\begin{array}{c}0.2360 \\
(1.37) \\
\end{array}$ & $\begin{array}{c}0.1874 \\
(1.35) \\
\end{array}$ & $\begin{array}{c}0.1613 \\
(1.44) \\
\end{array}$ & $\begin{array}{l}0.3268 \\
\left(1.94^{*}\right) \\
\end{array}$ & $\begin{array}{l}0.2135 \\
(1.59) \\
\end{array}$ & $\begin{array}{l}0.2001 \\
\left(1.71^{*}\right) \\
\end{array}$ \\
\hline board_size & $\begin{array}{c}0.0901 \\
\left(2.15^{* * *}\right) \\
\end{array}$ & $\begin{array}{l}0.0805 \\
\left(2.35^{* *}\right) \\
\end{array}$ & $\begin{array}{l}0.0690 \\
\left(2.51^{* *}\right) \\
\end{array}$ & $\begin{array}{c}0.0948 \\
\left(2.32^{* * *}\right) \\
\end{array}$ & $\begin{array}{c}0.0854 \\
\left(2.62^{2 * * *}\right) \\
\end{array}$ & $\begin{array}{c}0.0753 \\
\left(2.65^{* * *}\right)\end{array}$ \\
\hline top1 & $\begin{array}{c}0.0002 \\
(0.07)\end{array}$ & $\begin{array}{c}-0.0009 \\
(-0.29) \\
\end{array}$ & $\begin{array}{c}-0.0009 \\
(-0.32) \\
\end{array}$ & $\begin{array}{c}0.0003 \\
(0.76)\end{array}$ & $\begin{array}{c}0.0003 \\
(0.83) \\
\end{array}$ & $\begin{array}{l}0.0001 \\
(0.41)\end{array}$ \\
\hline tenure & $\begin{array}{c}-0.0011 \\
(-0.32) \\
\end{array}$ & $\begin{array}{l}0.0001 \\
(0.06)\end{array}$ & $\begin{array}{c}-0.0002 \\
(-0.65) \\
\end{array}$ & $\begin{array}{c}-0.0002 \\
(-0.52) \\
\end{array}$ & $\begin{array}{c}-0.0002 \\
(-0.55) \\
\end{array}$ & $\begin{array}{l}-0.0003 \\
(-0.94) \\
\end{array}$ \\
\hline ceo & $\begin{array}{c}0.0743 \\
\left(3.86^{* * * *}\right) \\
\end{array}$ & $\begin{array}{c}0.0541 \\
\left(3.49^{* * * *}\right) \\
\end{array}$ & $\begin{array}{c}0.0385 \\
\left(3.09^{* * * *}\right) \\
\end{array}$ & $\begin{array}{l}0.0239 \\
(0.88) \\
\end{array}$ & $\begin{array}{l}0.0038 \\
(0.17) \\
\end{array}$ & $\begin{array}{c}-0.0024 \\
(-0.13) \\
\end{array}$ \\
\hline size & $\begin{array}{c}-0.0090 \\
(-1.50) \\
\end{array}$ & $\begin{array}{c}-0.0055 \\
(-1.13) \\
\end{array}$ & $\begin{array}{c}-0.0033 \\
(-0.84)\end{array}$ & $\begin{array}{c}-0.0078 \\
(-1.36)\end{array}$ & $\begin{array}{c}-0.0021 \\
(-0.47) \\
\end{array}$ & $\begin{array}{l}0.0012 \\
(0.31)\end{array}$ \\
\hline roe & $\begin{array}{c}0.0235 \\
(1.20) \\
\end{array}$ & $\begin{array}{c}0.0102 \\
(0.64) \\
\end{array}$ & $\begin{array}{l}0.0061 \\
(0.48) \\
\end{array}$ & $\begin{array}{l}0.0258 \\
(1.64)\end{array}$ & $\begin{array}{c}0.0160 \\
(1.27)\end{array}$ & $\begin{array}{c}0.0101 \\
(0.92)\end{array}$ \\
\hline lev & $\begin{array}{c}-0.0308 \\
(-0.81) \\
\end{array}$ & $\begin{array}{c}-0.0384 \\
(-1.25) \\
\end{array}$ & $\begin{array}{c}-0.0106 \\
(-0.43) \\
\end{array}$ & $\begin{array}{l}-0.0395 \\
(-1.03) \\
\end{array}$ & $\begin{array}{c}-0.0538 \\
\left(1.76^{*}\right) \\
\end{array}$ & $\begin{array}{c}-0.0367 \\
(-1.38) \\
\end{array}$ \\
\hline dnum & $\begin{array}{l}-0.0533 \\
\left(-2.68^{* *}\right) \\
\end{array}$ & $\begin{array}{c}-0.0441 \\
\left(-2.75^{* * * *}\right) \\
\end{array}$ & $\begin{array}{l}-0.0126 \\
\left(-2.16^{* * *}\right) \\
\end{array}$ & $\begin{array}{c}-0.0071 \\
(-0.35) \\
\end{array}$ & $\begin{array}{c}-0.0112 \\
(-0.69) \\
\end{array}$ & $\begin{array}{c}-0.0038 \\
(-0.27) \\
\end{array}$ \\
\hline level & $\begin{array}{l}0.0043 \\
(0.26) \\
\end{array}$ & $\begin{array}{c}-0.0063 \\
(-0.48) \\
\end{array}$ & $\begin{array}{c}-0.0126 \\
(-1.20) \\
\end{array}$ & $\begin{array}{c}-0.0040 \\
(-0.24) \\
\end{array}$ & $\begin{array}{c}-0.0013 \\
(-0.09) \\
\end{array}$ & $\begin{array}{l}0.0001 \\
(0.02)\end{array}$ \\
\hline constant & $\begin{array}{l}0.0003 \\
(0.00) \\
\end{array}$ & $\begin{array}{c}-0.0265 \\
(-0.22) \\
\end{array}$ & $\begin{array}{c}-0.0609 \\
(-0.62) \\
\end{array}$ & $\begin{array}{c}-0.1490 \\
(-1.00) \\
\end{array}$ & $\begin{array}{c}-0.1945 \\
(-1.63) \\
\end{array}$ & $\begin{array}{c}-0.2467 \\
\left(-2.37^{* *}\right) \\
\end{array}$ \\
\hline Industry and year & controlled & controlled & controlled & controlled & controlled & controlled \\
\hline obs & 252 & 252 & 252 & 252 & 137 & 137 \\
\hline $\mathrm{R}^{2}$ & 0.1437 & 0.1484 & 0.1332 & 0.1135 & 0.1151 & 0.1066 \\
\hline
\end{tabular}

$*, * *, * *$ mean significance level of $10 \%$, significance level of $5 \%$, and significance level of $1 \%$, respectively

\subsection{Regression Analysis of Resource Support and Market Response to Forced Resignation of Independent Directors of Universities}

The multiple regression results show that in the listed companies, especially in state-owned listed companies, the governance mechanism of the independent directors of universities as members of special committees is invalid. That is, the value of the independent directors of universities through consultation and supervision function is very limited, so do the independent directors of universities especially the independent directors of universities in nonstate-owned listed companies exert their value through resource support function?

Therefore, this paper then analyzes the specific mechanism of independent directors' resource support function. The resource support function of independent directors of universities is measured by whether they come from "985" or "211" universities or universities with national key major.
Relevant literature shows that the more resources are available to independent directors of universities from these universities, the better their reputation will be and the higher the value they will bring to the companies. Relevant regression results are shown in table 6.According to the test results of the full sample, when the event windows are $(-3,3)$ and $(-2,2)$, the reputation coefficients are -0.0311 and 0.0194 , respectively, which are significant at the significance level of $5 \%$ and $10 \%$, while the event window is $(-1,1)$, reputation coefficient has no significant influence on the negative market reaction of independent directors' resignation. This shows that the resource support function of the reputation of independent directors of universities does exist, and the better the reputation is, the more negative the market reaction of the resignation of independent directors of universities is. The reason for the difference in the significance of different event windows is that the statedependence of market response is ignored in the full-sample regression. Based on this, this paper tests the resource support function of non-state-owned listed companies. From the multiple regression results of non-state-owned listed companies, when the event windows are $(-3,3),(-2,2)$ 
and $(-1,1)$, the reputation coefficients are all significantly negatively correlated at the significance of $5 \%$, indicating that independent directors of universities in non-state- owned listed companies mainly reflect their value through the resource support function, which is consistent with hypothesis $\mathrm{H} 3$.

Table 6 Test results of hypothesis 3

\begin{tabular}{|c|c|c|c|c|c|c|}
\hline \multirow{2}{*}{ Variable } & \multicolumn{3}{|c|}{ Whole samples } & \multicolumn{3}{|c|}{ Samples of non-state-owned listed companies } \\
\hline & CAR(-3,3) & CAR(-2,2) & CAR(-1,1) & CAR $(-3,3)$ & CAR(-2,2) & CAR(-1,1) \\
\hline fame & $\begin{array}{c}-0.0311 \\
\left(-2.16^{* *}\right)\end{array}$ & $\begin{array}{l}-0.0194 \\
\left(-1.67^{*}\right)\end{array}$ & $\begin{array}{c}-0.0135 \\
(-1.43)\end{array}$ & $\begin{array}{c}-0.0726 \\
\left(-2.81^{* * *}\right)\end{array}$ & $\begin{array}{c}-0.0479 \\
\left(-2.28^{* *}\right)\end{array}$ & $\begin{array}{c}-0.0373 \\
\left(-2.31^{* * *}\right)\end{array}$ \\
\hline state & $\begin{array}{c}-0.0113 \\
(-0.72)\end{array}$ & $\begin{array}{c}-0.0194 \\
(1.53)\end{array}$ & $\begin{array}{l}-0.0202 \\
\left(-1.97^{* *}\right)\end{array}$ & & & \\
\hline ratio & $\begin{array}{c}0.2576 \\
(1.52)\end{array}$ & $\begin{array}{l}0.1964 \\
(1.43)\end{array}$ & $\begin{array}{c}0.1694 \\
(1.53)\end{array}$ & $\begin{array}{c}0.1510 \\
(0.46)\end{array}$ & $\begin{array}{c}0.2121 \\
(0.8)\end{array}$ & $\begin{array}{c}0.1656 \\
(0.82)\end{array}$ \\
\hline board_size & $\begin{array}{c}0.0954 \\
\left(2.27^{* *}\right)\end{array}$ & $\begin{array}{c}0.0816 \\
\left(2.40^{* *}\right)\end{array}$ & $\begin{array}{c}0.0680 \\
\left(2.48^{* *}\right)\end{array}$ & $\begin{array}{c}0.0245 \\
(0.29)\end{array}$ & $\begin{array}{c}0.0310 \\
(0.45)\end{array}$ & $\begin{array}{c}0.0183 \\
(0.34)\end{array}$ \\
\hline top1 & $\begin{array}{r}-0.0003 \\
(-0.08)) \\
\end{array}$ & $\begin{array}{c}-0.0001 \\
(-0.33) \\
\end{array}$ & $\begin{array}{c}-0.0001 \\
(-0.23) \\
\end{array}$ & $\begin{array}{c}-0.0004 \\
(-0.53) \\
\end{array}$ & $\begin{array}{c}-0.0005 \\
(-0.91) \\
\end{array}$ & $\begin{array}{c}-0.0003 \\
(-0.67) \\
\end{array}$ \\
\hline tenure & $\begin{array}{c}0.0001 \\
(0.24)\end{array}$ & $\begin{array}{c}0.0002 \\
(0.51)\end{array}$ & $\begin{array}{c}-0.0001 \\
(-0.35)\end{array}$ & $\begin{array}{c}0.0001 \\
(0.01)\end{array}$ & $\begin{array}{c}0.0003 \\
(0.46)\end{array}$ & $\begin{array}{c}-0.0001 \\
(-0.11)\end{array}$ \\
\hline ceo & $\begin{array}{c}0.0804 \\
\left(4.20^{* * *}\right)\end{array}$ & $\begin{array}{c}0.0588 \\
\left(3.80^{* * *}\right)\end{array}$ & $\begin{array}{c}0.0412 \\
\left(3.30^{* * *}\right)\end{array}$ & $\begin{array}{c}0.0983 \\
\left(3.56^{* * *}\right)\end{array}$ & $\begin{array}{c}0.0793 \\
\left(3.53^{* * *}\right)\end{array}$ & $\begin{array}{c}0.0571 \\
\left(3.31^{* * *}\right)\end{array}$ \\
\hline size & $\begin{array}{l}-0.0104 \\
\left(-1.77^{*}\right)\end{array}$ & $\begin{array}{c}-0.0067 \\
(-1.42)\end{array}$ & $\begin{array}{c}-0.0042 \\
(-1.09)\end{array}$ & $\begin{array}{c}-0.0136 \\
(-1.12)\end{array}$ & $\begin{array}{c}-0.0119 \\
(-1.21)\end{array}$ & $\begin{array}{r}-0.0107 \\
(-1.42)\end{array}$ \\
\hline roe & $\begin{array}{c}0.0244 \\
(1.27)\end{array}$ & $\begin{array}{c}0.0107 \\
(0.69)\end{array}$ & $\begin{array}{c}0.0077 \\
(0.61)\end{array}$ & $\begin{array}{c}0.0902 \\
(0.95)\end{array}$ & $\begin{array}{c}0.0151 \\
(0.20)\end{array}$ & $\begin{array}{c}0.0250 \\
(0.42)\end{array}$ \\
\hline lev & $\begin{array}{c}-0.0028 \\
(0.17)\end{array}$ & $\begin{array}{c}-0.0301 \\
(-1.00)\end{array}$ & $\begin{array}{c}-0.0034 \\
(-0.14)\end{array}$ & $\begin{array}{c}0.0154 \\
(0.22)\end{array}$ & $\begin{array}{c}0.0087 \\
(0.15)\end{array}$ & $\begin{array}{c}0.0442 \\
(1.02)\end{array}$ \\
\hline dnum & $\begin{array}{l}-0.0430 \\
\left(-2.22^{* *}\right)\end{array}$ & $\begin{array}{c}-0.0354 \\
\left(-2.26^{* *}\right)\end{array}$ & $\begin{array}{l}-0.0218 \\
\left(-1.72^{* *}\right)\end{array}$ & $\begin{array}{l}-0.0920 \\
\left(-2.50^{* *}\right)\end{array}$ & $\begin{array}{c}-0.0681 \\
\left(-2.27^{* *}\right)\end{array}$ & $\begin{array}{c}-0.0458 \\
\left(-1.99^{* *}\right)\end{array}$ \\
\hline level & $\begin{array}{c}0.0028 \\
(0.17)\end{array}$ & $\begin{array}{c}-0.0069 \\
(-0.53)\end{array}$ & $\begin{array}{c}-0.0130 \\
(-1.24)\end{array}$ & $\begin{array}{c}0.0111 \\
(0.39)\end{array}$ & $\begin{array}{c}-0.0129 \\
(-0.55)\end{array}$ & $\begin{array}{c}-0.0255 \\
(-1.42)\end{array}$ \\
\hline constant & $\begin{array}{c}-0.0061 \\
(-0.04)\end{array}$ & $\begin{array}{c}-0.0233 \\
(-0.19)\end{array}$ & $\begin{array}{c}-0.0580 \\
(-0.59)\end{array}$ & $\begin{array}{l}0.3137 \\
(1.02)\end{array}$ & $\begin{array}{c}0.2378 \\
(0.95) \\
\end{array}$ & $\begin{array}{c}0.2222 \\
(1.16) \\
\end{array}$ \\
\hline Industry and year & controlled & controlled & controlled & controlled & controlled & controlled \\
\hline obs & 252 & 252 & 252 & 115 & 115 & 115 \\
\hline $\mathrm{R}^{2}$ & 0.1449 & 0.1444 & 0.1241 & 0.2226 & 0.2051 & 0.2075 \\
\hline
\end{tabular}

$*, * *, * * *$ mean significance level of $10 \%$, significance level of $5 \%$, and significance level of $1 \%$, respectively

\subsection{Further Research and Robustness Test}

The above test results of hypothesis 2 show that, in listed companies, especially in state-owned listed companies, the governance mechanism of independent directors of universities serving as members of special committees does not play an active role in supervision and consultation. Then how do independent directors of universities play a role in state-owned listed companies?

In this paper, on the basis of the above model, the degree of independent directors of universities is as explanatory variable to run the regression again. The study finds that the degree of independent directors of universities is negatively related to market reaction on the resignation of independent directors of universities, that is to say, independent directors of universities in state-owned listed companies do exert governance function with their professional expertise and quickly thinking ability.

In addition, this paper chooses different windows and value weighting methods to calculate the cumulative abnormal rate of return, and tests the robustness of the three hypotheses. The results show that the coefficient size, direction and significance level of the main explanatory variables have not changed significantly (due to length limitations, the results are not listed).

\section{CONCLUSION AND DISCUSSION}

Different from the existing literature, which mainly focuses on the value and function of independent directors, this paper takes the "Notice" issued by the Ministry of Education in November 2015 as an exogenous event, and uses the Event Research Method regression to investigate the market reaction of forced resignation of independent directors of universities, and to test the value and function mechanism of independent directors of universities. It is found that:

(1) the market has a significant reaction to the forced resignation of independent directors of universities, and the market reaction is state-dependent, that is, the market reaction of state-owned listed companies is significantly negative, while the market reaction of non-state-owned listed companies is significantly positive;

(2) Different with the purpose of the special committee to be set up, the effectiveness of governance mechanism of independent directors of universities as a special committee 
is poor, especially in the state-owned listed companies. The value of independent directors of universities in state-owned listed companies mainly depends on their own professional ability and quickly thinking ability, but it is not obvious.

(3) Independent directors of universities provide their value mainly through resource support. Especially for non-stateowned listed companies lack of resources, independent directors of universities bringing intangible assets is critical to the survival and development of enterprises. The richer resources independent directors of universities bring, the more significant market reaction is. But in the long run, the way is not conductive to purify capital markets and the efficient allocation of resources, even distort the fundamental function of independent directors of universities. The above research results show that although the independent director system is not satisfactory, but we cannot deny the value and the positive role of independent directors in China's corporate governance practice.

As a typical country in transition economy, it is impossible to improve the level of corporate governance in a short time by relying on formal institutional norms and developing the capital market and learning from the successful institutional experience of foreign countries. The reform and improvement of the independent director system should start from the realistic situation and constraint conditions of the development of China's capital market and gradually remove the obstacles to exerting the value of the independent director system. Combined with the research conclusion, this paper believes that the management and standardization of independent directors of universities should be strengthened, the resource differences and reputation differences between independent directors should be further narrowed, and the non-state-owned listed companies should gradually stop using independent directors of universities to obtain intangible assets and make up for the shortage of resources, and the value of independent directors in special committees should be enhanced. In personnel setting, improve the proportion of independent directors in the special committees, strengthening the rights of the independent directors on execution mechanism, reduce the management's influence on the special committees, perfect supervision mechanism, urge independent directors to make reasonable compensation contracts, objectively evaluate the strategic decision and management, make independent directors play a better role on supervision and advisory function.

This paper also has the following research deficiencies: the fact that the whole process of independent directors of universities performing their duties cannot be observed in reality, which may lead to the omission of some important variables in the regression models. For example, the process of independent directors' participation in voting in the special committee and the operation of the special committee may have certain explanatory power for the market reaction of independent directors. Therefore, in addition to considering the influence of independent directors' position in the special committee, professional title and educational background on the supervision and advisory function of independent directors of universities, the future research should focus on the influence of the operation mechanism of the special committee and the diligence of independent directors on the value of independent directors.

\section{Fund Project:}

Jiangsu University Philosophy and Social Science Fund Project "Research on the Influence of Tax on Enterprise Innovation Efficiency from the Perspective of Risk-taking" (2019SJA0409); Hunan Social Science Fund Project "CEO power, Political Resources and Enterprise innovation Research (16YBQ061)"

\section{REFERENCES}

[1] Malkiel B G, Fama E F. Efficient capital markets: A review of theory and empirical work $[\mathrm{J}]$. The journal of Finance, 1970, 25(2): 383-417.

[2] Fama E F, Jensen M C. Separation of ownership and control[J]. The journal of law and Economics, 1983, 26(2): 301-325.

[3] Xiaofei Deng, yu Xin, fei Teng. The forced resignation of official independent directors and the loss of political ties [J]. China's industrial economy, 2016 (2) : 130-145.

[4] yan Jiang, yunfeng Xia, weihua $\mathrm{Cu}$, et al. Equity relationship in banks, CEO power and corporate innovation [J]. Journal of financial science, 2017 (2): 25-37.

[5] Abbott L J, Parker S, Peters G F. Audit committee characteristics and restatements[J]. Auditing: A Journal of Practice \& Theory, 2004, 23(1): 69-87.

[6] zhonglian Yang, zi Yin. Audit committee, research on supervision effect of independent directors -- evidence from financial fraud [D]. Journal of Shanghai University of Finance and Economics: 2006, (1)93-97

[7] jianbo Niu, xiguang Liu. Effectiveness of board committee and governance premium -- based on the experience of Chinese listed companies [J]. Securities market guide, 2008, 2008(1): 64-72.

[8] weihua $\mathrm{Cu}$.Value of independent directors: evidence from resignation of independent directors [J]. Economic Management, 2015,37(3):56-66.

[9] Rujing Ma, Xuesong Tang. Independent directors with academic background, corporate performance and CEO change [J]. Journal of Financial Science, 2016(9):77-87.

[10] Adams M, Jiang W. Do outside directors influence the financial performance of risk-trading firms? Evidence from the United Kingdom (UK) insurance industry[J]. Journal of Banking \& Finance, 2016, 64: 36-51. 
[11] xiang Rui. Characteristics of independent financial director and accounting conservatism [J]. Journal of Shanxi University of Finance and Economics, 2014, (06):102-112

[12] Liu Y, Miletkov M K, Wei Z, et al. Board independence and firm performance in China[J]. Journal of Corporate Finance, 2015, 30: 223-244.

[13] Fang Zhao, Zhe Sun, Xingkai Nie. Local independent directors in the audit committee and stock price crash [J]. Audit Research, 2017(5):104-112.

[14] Agrawal A, Chen M A. Boardroom brawls: An empirical analysis of disputes involving directors[J]. Quarterly Journal of Finance, 2017, 7(03): 1750006.

[15] Qianhua Lei, Danglun Luo, Huili Chen. What is the role of independent directors of listed companies? - the perspective of the market perception of the resignation of independent directors of Chinese listed companies [J]. Symposium of Finance and Economics, 2017(4):61-70.

[16]yunsen Chen, deren Xie. Director network, independent director governance and executive motivation[J]. Finance research, 2012 (2) : 168-182.

[17] Booth J R, Deli D N. Factors affecting the number of outside directorships held by CEOs[J]. Journal of Financial Economics, 1996, 40(1): 81-104.

[18] Farina V. Banks' centrality in corporate interlock networks: evidences in Italy[J]. Available at SSRN 1343641, 2009.

[19] Chun Liu, Shanmin Li, Liang Sun. Do independent directors have advisory function? - empirical research on the function of remote independent directors in remote mergers and acquisitions [J]. Management World,2015(3)

[20] Lin N. Social capital: A theory of social structure and action[M]. Cambridge university press, 2002.

[21] Vafeas N. Board meeting frequency and firm performance[J]. Journal of financial economics, 1999, 53(1): 113-142.

[22] Shilei Xie, Yongbin Xu, Zhouli Hu. Busy Directors, Reputation incentive and independent director supervision behavior [J]. Journal of Xiamen University,2016(5):147156.

[23] jianqiong Wang, xianwei Lu. Director reputation, busy board and quality of information disclosure [J]. Audit and economic research, 2013 (4): 67-74.

[24] Nguyen B D, Nielsen K M. The value of independent directors: Evidence from sudden deaths[J]. Journal of financial economics, 2010, 98(3): 550-567.

[25] Brown S J, Warner J B. Using daily stock returns: The case of event studies[J]. Journal of financial economics, 1985, 14(1): 3-31.

[26] Haijie Huang, Changjiang Lv, Hui Ding. Reputation of independent directors and earnings quality -- the perspective of independent directors of accounting profession [J]. Management World, 2016(3):128-143. 